\title{
Swiss Student's Arguments in Favour and against a Career in Primary Care
}

\author{
Larissa R Burghardt ${ }^{1}$, Michaela Dreisbach ${ }^{2}$, Hossein Shahla ${ }^{3}$ and Adrian P Businger ${ }^{4 *}$ \\ ${ }^{1}$ Department of Internal Medicine, Spital Altstätten, Altstätten, Switzerland \\ ${ }^{2}$ Department of Internal Medicine, Regionalspital Emmental AG, Burgdorf, Switzerland \\ ${ }^{3}$ German Federal Institute for Medical and Pharmaceutical Examination Questions (IMPP), Mainz, Germany \\ ${ }^{4}$ Department of Surgery, Regionalspital Emmental AG, Burgdorf, Switzerland
}

\begin{abstract}
Background: Interest in a career in Primary Care has alarmingly waned among medical school graduates in Western countries; the number of Primary Care Physicians (PCP) is clearly insufficient to cover future needs. Qualitative studies in which medical students express their interest in a career in Primary Care are scarce.
\end{abstract}

Objective: To estimate the percentage of medical students planning to start a career in Primary Care, to analyse statements in favour of and against a career in Primary Care given by sixth-year medical students, and to compare these statements with those of younger medical students.

Methods: A questionnaire was mailed to sixth-year medical students in 2008, soliciting three answers in favour of and three answers against a career in Primary Care, and the results were qualitatively assessed and compared to the statements of first- to fourth-year medical students attending continuing medical education. In addition, participants indicated whether or not they aspired to become a PCP.

Results: A total of 2,502 statements in favour of and against a career in primary care were given by 302 sixth year medical students and 112 first- to fourth-year medical students. The overall response rate was $73.8 \%$. The most frequently occurring positive categories, "Experience in Daily Practice" and "Professional Interactions", accounted for $83 \%$ of all positive statements. The most frequently occurring negative category was "Working Conditions" (24.8\%). Of the 414 participants, 59 (14.3\%) choose to become a PCP $(7.1 \%$ of first-to fourth-year students versus $16.9 \%$ of sixthyear medical students; $p=0.012)$. The analysis of students' statements detected only few differences between gender, year of study and the interest to become a PCP or not.

Conclusions: The given statements assigned to the different categories highlighted the current difficult and uncertain situation of primary care concerning health policy and income. During medical school, the fraction of those planning to go into PC is slightly increasing. Nonetheless, only a small percentage of medical school graduates intend to become a PCP. Therefore, there is an urgent need to increase the attractiveness of primary care by broadening the PCP's professional experience, as well as establishing an assured remuneration appropriate to the individual level of specialisation.

Keywords: Primary care; Medical students; Career choice; Quantitative content analysis

\section{Introduction}

As it is the case in many other Western countries, the dearth of junior primary care practitioners (PCP) is of paramount concern in the health care system in Switzerland. This problem is anticipated to grow even more in the foreseeable future, considering that general practitioners, in Switzerland, for example, are on average older than specialists, that more than 50 per cent are at least 50 years old, and that a majority of them will reach retirement age in about 10 years [1]. This statistic is even worse than it seems because, above all, elderly people tend to consult PCP, people aged 65 years and older are more likely to have chronic-care needs, and the elderly are the fastestgrowing age group in Western countries. In Switzerland in 2007, only $1.04 \%$ (93/8935) of all residencies was in Primary Care, only $16.03 \%(4005 / 24986)$ of all practicing physicians were PCP, and only $13.96 \%$ (139/996) of all newly qualified physicians were specialised in Primary Care [1]. The numbers of PCP per thousand inhabitants in Switzerland decreased from 0.57 in 1990 to 0.45 in 2010. The Swiss Health Observatory is anticipating a huge gap for outpatient consultations coverage, forecasting non-coverage of 40 per cent of outpatient consultations (9.3 million) in 2030 [2]. There are several publications concerning the reasons for the declining interest in a career in medicine, especially in Primary Care [3-6], some of which parallel reasons for the drop in medical school graduates in Switzerland during the past years, concurrent with a relatively unchanging number of medical students since 1980 . One problem may be that medical students are given relatively little exposure to lectures on Primary Care and one-on-one tutorials in basic medical education [7]. Most importantly, however, is the perception that PCP' lives are stressful, that the work hours are long, that a controllable lifestyle is difficult to realise $[8,9]$, and that the economic incentives, one of the most critical and pressing issues in students' career choice [10], are lower than those of other specialists. Even if young physicians consider Primary Care an interesting field [11], the attractiveness of Primary Care for students and young physicians has waned on different levels, made apparent by the notable number of medical students initially interested in Primary

*Corresponding author: Adrian P Businger, Department of Surgery, Regionalspital Emmental AG, Oberburgstrasse 54, CH-3400 Burgdorf, Switzerland, Tel: +41-34421-2279; Fax: +41-34-421-2299; E-mail: adrian.businger@gmx.ch

Received March 31, 2012; Accepted May 19, 2012; Published May 21, 2012

Citation: Burghardt LR, Dreisbach M, Shahla H, Businger AP (2012) Swiss Student's Arguments in Favour and against a Career in Primary Care. Primary Health Care 2:114. doi:10.4172/2167-1079.1000114

Copyright: (c) 2012 Burghardt LR, et al. This is an open-access article distributed under the terms of the Creative Commons Attribution License, which permits unrestricted use, distribution, and reproduction in any medium, provided the original author and source are credited. 
Care but who subsequently changed their choice of speciality over the course of medical school $[12,13]$, and by the steadily decreasing number of graduates choosing Primary Care $[14,15]$. In fact, Primary Care is markedly affected by the profound changes which are taking place at a dizzying pace in most of Western healthcare systems due to economic, bureaucratic, and political initiatives. In Switzerland, for example, this is due to the national relative value scale for reimbursement (TARMED) since 2004, to nationwide restricted work hours for all residencies beginning January 1st 2005, to an ongoing moratorium on accreditation of new practices since summer 2002, or to the new compensation system for PCP' laboratory service. It is generally acknowledged that loss of job autonomy and income within a speciality make students hesitant to select it $[16,17]$. In the medical community in Western countries, all these above-mentioned facts have initiated a broad-based discussion about the future of Primary Care and possible corrective actions [11,18-20]. However, to date, studies on the interest in a career in Primary Care among medical students in Switzerland have been scarce. Some have investigated the interest of fourth-year residents to become a PCP [21,22], or more generally, whether or not the original decision to become a physician persists throughout medical school [4]. Studies in which medical students express their concerns about a career in Primary Care in an openended fashion are lacking in the current scientific literature.

The objective of the present study was three-fold: First, to estimate the percentage of medical students planning to start a career in Primary Care, second, to analyse statements in favour of and against a career in Primary Care given by sixth-year medical students, and, third, to compare these statements with those of younger medical students.

\section{Methods}

\section{Data collection}

A postal anonymous survey of sixth-year (i.e. final year in Switzerland) medical students was conducted in 2008 at the three medical schools in German-speaking Switzerland (University of Bern, University of Zurich, and University of Basel) to elicit their opinions about a career in Primary Care. In our survey "Primary Care" was used synonymously with Family Medicine or General Medicine. Furthermore, from medical-student attendees at a continuing medical education conference in Emergency Medicine in autumn 2008 we randomly recruited participants at different levels in their medical studies to complete the same self-administered questionnaire. There were no fifth-year medical students participating in this survey, because they are all doing their clerkship. Confidentiality was ensured, and participants sent their anonymous responses to an independent administration office. As the survey addressed healthy people on a voluntary basis without any incentives, no further ethical considerations were required.

\section{Statements}

The solicited opinions in favour of and against a career in Primary Care were in response to a request to give three statements each in favour of and against a career in Primary Care. In addition, participants had to indicate whether or not they aspired to become a PCP. Additional participants' information was extracted from a general form containing questions about gender, age, year of medical school, and whether or not the respondents' parents are PCP. Furthermore, the participants were asked to indicate whether or not they were influenced in their career choice by meeting with a PCP during medical school, the current discussion in the lay media about the significance of Primary Care, or the estimation of Primary Care given by academics.

\section{Statistical analysis}

The quantitative statistics were performed with SPSS ${ }^{\circledR} 20.0$ (SPSS; Chicago, Illinois, USA). The quantitative content analyses were done by an independent researcher trained in qualitative data analysis (HS), using the Mayring's content analysis [23], first, by transcribing the handwritten statements, second, by defining the level of abstraction for the inductive formation of categories, and, third, by stepwise inductive formulating of content categories and generating of a code manual. Then, a formative check of reliability was made, followed by a summative check of reliability. A second rater did partial coding on $20 \%$ of the statements; the overall agreement of the eight codes was $78.2 \%$, with a kappa value of 0.82 . Comparisons of dichotomous outcomes were performed by $\chi^{2}$ or Fisher's exact test. $\mathrm{P}<0.05$ was considered statistically significant. All tests were two-sided.

\section{Results}

A total of 561 students (396 sixth-year students and 165 students at levels other than final year) were invited to complete the questionnaire, and 302/396 sixth-year students (76.3\%) and 112/165 first to fourth year students $(67.9 \%)$ were willing to take part, yielding an overall response rate of $73.8 \%$. Thus, the total number of completed questionnaires was 414 . The median age was 25 (range 18-48) years, and $270 / 414$ respondents $(65.2 \%)$ were female. (Table 1 ) provides a detailed description of the study participants.

\section{Categories and statements for a career in primary care}

The 414 participants provided a total of 2,502 statements $(1,253$ statement in favour of and 1,249 against a career in Primary Care) assigned to eight different categories both in favour of and against a career in Primary Care according to the content analysis; the number and content of these categories were identified by inductive formation and then by stepwise inductive formulating as described above [23]. Such statements as "To have the possibility of takeover of a practice with patient base" or "not to have research activity" were classified as not codeable. The categories given for the statements for a career in Primary Care are as follows, listed in decreasing frequency distribution of the positive statements: "Experience in Daily Practice" (48.1\%), "Professional Interactions" (34.9\%), "Working Conditions" (10.1\%), "Private Life" (2.4\%), "Prestige" (0.7\%), "Training Conditions" (0.4\%), "Meaning" (0.2\%), and "Income" (0.2\%). Examples of students' statements in favour of and against a career in Primary Care are shown in (Table 2). In all 1,167 positive answers (93.1\%) occupied the first three places in the ranking of all given answers; the ranking was almost the same for men and women (Table 3). There were some gender differences in frequency distribution of the answers: women gave more positive statements in the category, "Working Conditions" $(11.5 \%$ versus $7.5 \% ; \mathrm{p}=0.026$ ), and men named more positive statements in the categories, "Experience in Daily Practice" (52.2\% versus $46.1 \%$; $\mathrm{p}=0.044)$ and "Prestige" ( $1.4 \%$ versus $0.4 \% ; \mathrm{p}=0.032)$. In the category, "Working Conditions", more positive statements were given by firstyear to fourth-year medical students than by sixth year medical students (13.3\% versus $9.0 \% ; \mathrm{p}=0.030$ ) (Table 4 ), and by students without a PCP as parent compared to those with a PCP as a parent (10.8\% versus $4.3 \% ; p=0.028$ ). The latter subset of respondents made more positive statements in the category, "Experience in Daily Practice", than did students without a PCP as parent (58.6\% versus $47.0 \%$; $\mathrm{p}=0.017$ ) (Table 5). In the same category "Experience in Daily Practice", participants who 
Citation: Burghardt LR, Dreisbach M, Shahla H, Businger AP (2012) Swiss Student's Arguments in Favour and against a Career in Primary Care. Primary Health Care 2:114. doi:10.4172/2167-1079.1000114

Page 3 of 7

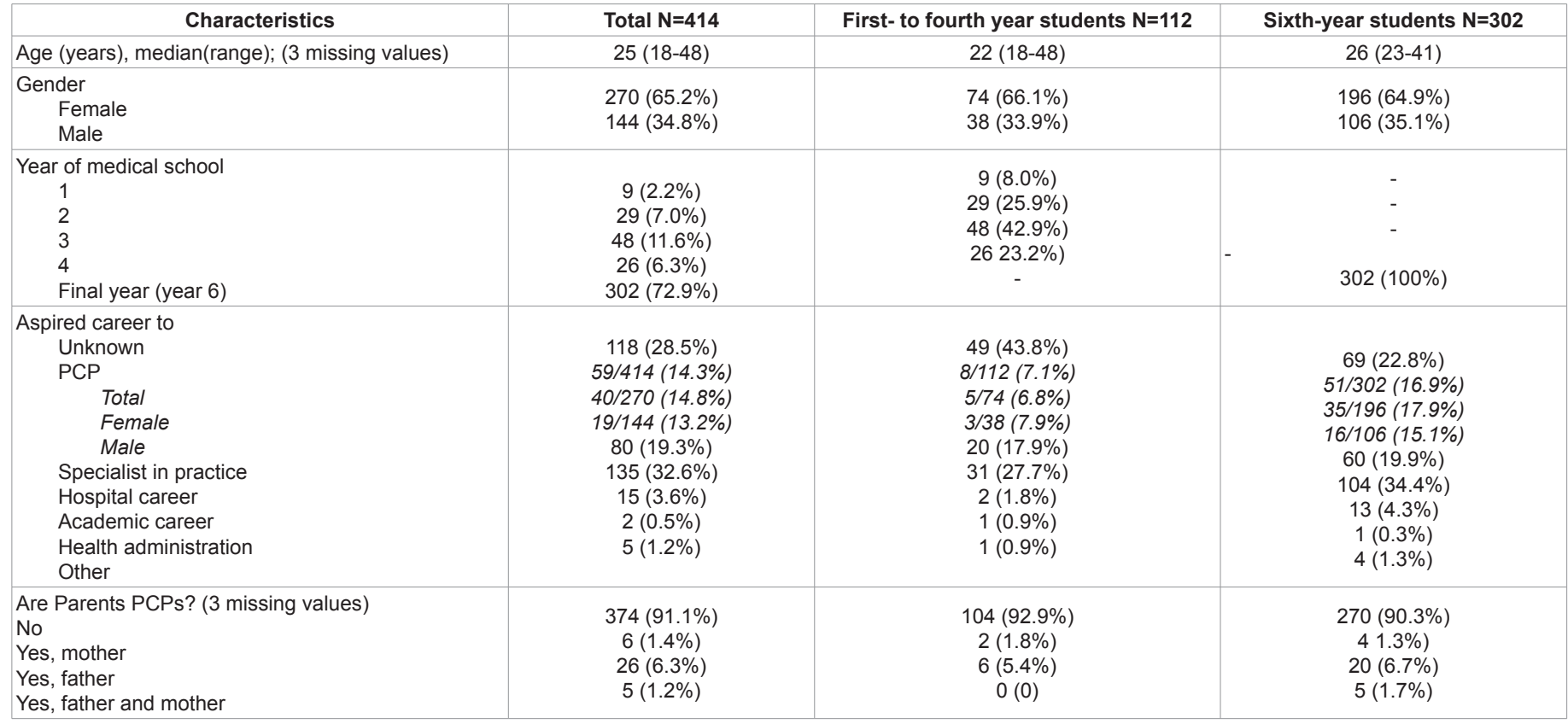

Fifth-year medical students were not reached (clerkship students). PCP: Primary Care Physician

Table 1: Demographics of 414 participants.

\begin{tabular}{|c|c|c|}
\hline Category & Statements in favour of a career in Primary Care & Statements against a career in Primary Care \\
\hline 1 Experience in Daily Practice & $\begin{array}{l}\text { "Daily contact with a broad spectrum of diseases" } \\
\text { "Diversified medical knowledge needed to make initial diagnosis" } \\
\text { "No internal competition compared to the hospital setting" } \\
\text { "Possibility to create one's own working climate" }\end{array}$ & $\begin{array}{l}\text { "Interesting cases frequently have to be referred to specialists" } \\
\text { "Burden due to recurring job routine" } \\
\text { "Increasing risk of bad decisions due to cost- and time pressure" } \\
\text { "Absence of challenging interventions" }\end{array}$ \\
\hline 2 Professional Interactions & $\begin{array}{l}\text { "Intensive and personal doctor-patient relationship over a longer } \\
\text { time period" } \\
\text { "Integrated and life-relevant patient care" } \\
\text { "Diversified activities in a small team" }\end{array}$ & $\begin{array}{l}\text { "Too personal contact with patients" } \\
\text { "Increasingly unrealistic patients' Expectations" } \\
\text { "A small team with very few possibilities for exchange" } \\
\text { "A lot of psychosomatic or psychiatrically conspicuous patients" }\end{array}$ \\
\hline 3 Working Conditions & $\begin{array}{l}\text { "Possibility of part-time working in group Practice" } \\
\text { "Worthwhile autonomy to design one's own working environment" } \\
\text { "Flexibility in working-time arrangement" } \\
\text { "No strong clinic business, but individual working in a small team" }\end{array}$ & $\begin{array}{l}\text { "Long and energy-consuming work hours and presence time" } \\
\text { "Professional dead end, loneliness" } \\
\text { "Development of health care politics with increasing governmental } \\
\text { and health economic restrictions" }\end{array}$ \\
\hline 4 Private Life & $\begin{array}{l}\text { "More time available for individual plans for the future" } \\
\text { "A family compatible field in medicine with the possibility of prac- } \\
\text { tice and living at the same place" } \\
\text { "Possibility to have time for family work" }\end{array}$ & $\begin{array}{l}\text { "The current emergency medical service hampers the planning abil- } \\
\text { ity of leisure time" } \\
\text { "Slave of the public due to the expectation of being permanently } \\
\text { available" }\end{array}$ \\
\hline 5 Prestige/social appreciation & $\begin{array}{l}\text { "Prestige within the village community" } \\
\text { "A distinctive social affiliation to the Village" }\end{array}$ & $\begin{array}{l}\text { "General practitioning is estimated as lower valued compared to } \\
\text { specialists by the society" } \\
\text { "Disadvantageous health politics (ongoing moratorium on accredita- } \\
\text { tion of new practices, national relative value scale for remuneration } \\
\text { TARMED)" }\end{array}$ \\
\hline 6 Further Training Conditions & $\begin{array}{l}\text { "Fast-track curriculum" } \\
\text { "Liberal choice of continuing training" } \\
\text { "Interesting advanced training curriculum" }\end{array}$ & $\begin{array}{l}\text { "Anyone can become a PCP without a selection of candidates" } \\
\text { "No career opportunites" } \\
\text { "Only little specialisation possible with a limitation of professional } \\
\text { development" }\end{array}$ \\
\hline 7 Meaning & $\begin{array}{l}\text { "Highly satisfying medical field" } \\
\text { "Importance of the profession itself" }\end{array}$ & $\begin{array}{l}\text { "To pay a high price with exorbitant selfsacrifice" } \\
\text { "One lives only for the profession" }\end{array}$ \\
\hline 8 Income & $\begin{array}{l}\text { "More credit for Primary Care will be } \\
\text { given in the future, especially fiscally" }\end{array}$ & $\begin{array}{l}\text { "Financial uncertainty will increase in the near future" } \\
\text { "Financial disadvantage compared to Specialists" } \\
\text { "Continuing anxiety about the economic prospects of the practice" }\end{array}$ \\
\hline
\end{tabular}

PCP: Primary care physician.

Table 2: Examples of students' statements in favour of and against a career in Primary Care.

indicated that the meeting with a PCP during their studies positively influenced their career choice but do not aspire to become PCP or are yet undecided, stated significantly more positive statements than did participants who are deterred from a career as PCP by a meeting with a PCP (51.6\% versus $40.9 \%$; $\mathrm{p}=0.010)$.

\section{Statements against a career in primary care}

In the ranking of negative statements there were some differences between male and female students: Women ranked the category, "Working Conditions", first and "Experience in Daily Practice" second, whereas men ranked the latter category first, "Income" second, and 
put "Working Conditions" in third place. Even not significant, more negative statements were given in the category, "Working Conditions", by women than by men (Table 3). Sixth-year medical students gave more negative statements in the category, "Working conditions", than did first-year to fourth-year students (26.2\% versus $20.7 \%$; $\mathrm{p}=0.048)$. Furthermore, there are significant differences for statements against a career in Primary Care given by participants who are not interested to pursue a career in Primary Care in two categories: Sixth-year medical students made significantly more critical statements vis-à-vis “Working Conditions" (25.7\% versus $19.8 \%$; $\mathrm{p}=0.044$ ), and first to fourth year students made significantly more statements against a career in Primary Care in the category, "Professional Interactions" (5.5\% versus $2.8 \% ; \mathrm{p}=0.039$ ). In all other categories there were almost no differences regarding the statements of students of various study years. The statements against a career in Primary Care did not differ significantly between participants with and without a parent who is a PCP (Table 5).

\section{To become a PCP or not}

Of the 414 participants, 59 (14.3\%) intend to become a PCP (firstyear to fourth-year students: $7.1 \%$ versus sixth-year medical students $16.9 \% ; \mathrm{p}=0.012$ ), and 355 (85.7\%) indicated no interest to do so. There was no significant gender difference concerning a career aspiration in Primary Care, but a trend (male 9.7\% versus female $16.7 \%$; $\mathrm{p}=0.054$ ). Students with a PCP as a parent do not choose Primary Care as a career more often than do other participants. The frequency distribution of given statements for a career in Primary Care differed in the category, "Further Training Conditions", significantly between those who would become a PCP and those who would not ( $1.5 \%$ versus $0.2 \%$; $=0.006$ ) There were significant differences in statements against a career in Primary Care in the category, "Experience in Daily Practice", where more negative statements were given by those who would not become a PCP (26.1\% versus $15.9 \%$; $\mathrm{p}=0.003)$, and in the category, "Income", where more negative statements were given by those who would become a PCP (29.1\% versus $21.6 \%$; $\mathrm{p}=0.026)$ (Table 6 ).

\section{Discussion}

For the first time we used a quantitative content analysis approach to analyse students' interest in a career in Primary Care [23], yielding eight different answer categories. The top-ranked categories, "Experience in Daily Practice" and "Professional Interactions" accounted for more than $80 \%$ of all positive statements. The top-ranked negative category was "Working Conditions" (24.8\%); only every seventh student aspired to become a PCP. The analysis of students' statements revealed only few differences depending on gender, year of study and the interest to become a PCP or not.

The survey took place in a time when a clear and urgent need to save the profession of the PCP already loomed in industrialised nations $[15,21]$. Indeed, PCPs are an "endangered species" due to ageing of the population, coupled with the fact that there is steadily waning interest in becoming a PCP among the younger generation in Western countries. Working in a challenging field, PCPs are condemned to struggle due to reduced economic resources and room for development coupled with increasing demands and work [8]. The most-frequently given argument categories in favour of a career in Primary Care were

\begin{tabular}{|c|c|c|c|c|c|c|}
\hline \multirow[t]{2}{*}{ Category } & \multicolumn{3}{|c|}{ Statements in favour of a career in Primary Care } & \multicolumn{3}{|c|}{ Statements against a career in Primary Care } \\
\hline & Men & Women & $P \ddagger$ & Men & Women & $P \ddagger$ \\
\hline Experience in Daily Practice & $217(52.2)$ & $386(46.1)$ & 0.044 & $107(25.5)$ & $200(24.1)$ & 0.600 \\
\hline Professional Interactions & $135(32.5)$ & $302(36.1)$ & 0.204 & $15(3.6)$ & $28(3.4)$ & 0.859 \\
\hline Working Conditions & $31(7.5)$ & $96(11.5)$ & 0.026 & $91(21.7)$ & $219(26.4)$ & $219(26.4)$ \\
\hline Private Life & $9(2.2)$ & $21(2.5)$ & 0.706 & $16(3.8)$ & $39(4.7)$ & 0.466 \\
\hline Prestige & $6(1.4)$ & 6 & 0.032 & $37(8.8)$ & $66(8.0)$ & 0.607 \\
\hline Further Training Conditions & $2(0.5)$ & $3(0.4)$ & 0.746 & $40(9.5)$ & $69(8.3)$ & 0.478 \\
\hline Meaning & $2(0.5)$ & $1(0.1)$ & 0.218 & $1(0.2)$ & $1(0.1)$ & 0.624 \\
\hline Income & $0(0)$ & $3(0.4)$ & 0.222 & $100(23.8)$ & $184(22.2)$ & 0.520 \\
\hline Not codeable & $14(3.4)$ & $22(2.6)$ & 0.462 & $13(3.1)$ & $23(2.8)$ & 0.749 \\
\hline Total & $416(100)$ & $837(100)$ & & $420(100)$ & $829(100)$ & \\
\hline
\end{tabular}

Values in parentheses are percentages. $\mp X^{2}$ test.

Table 3: Frequency distribution of statements in favour of $(n=1,253)$ and against $(n=1,249)$ a career in Primary Care given by 270 female and 144 male medical students, listed by positive statements.

\begin{tabular}{|c|c|c|c|c|c|c|}
\hline \multirow[t]{2}{*}{ Category } & \multicolumn{3}{|c|}{ Statements in favour of a career in Primary Care } & \multicolumn{3}{|c|}{ Statements against a career in Primary Care } \\
\hline & $1^{\text {st }}$ to $4^{\text {th }}$-year & $6^{\text {th }}$-year & $\mathrm{P} \ddagger$ & $1^{\text {st }}$ to $4^{\text {th }}$-year & $6^{\text {th }}$-year & $P \ddagger$ \\
\hline Experience in Daily Practice & $146(45.1)$ & $457(49.2)$ & 0.200 & $82(25.7)$ & $225(24.2)$ & 0.588 \\
\hline Professional Interactions & $105(32.4)$ & $332(35.7)$ & 0.279 & $16(5.0)$ & $27(2.9)$ & 0.074 \\
\hline Working Conditions & $43(13.3)$ & $84(9.0)$ & 0.030 & $66(20.7)$ & $244(26.2)$ & 0.048 \\
\hline Private Life & $12(3.7)$ & $18(1.9)$ & 0.073 & $13(4.1)$ & $42(4.5)$ & 0.741 \\
\hline Prestige & $4(1.2)$ & $5(0.5)$ & 0.201 & $28(8.8)$ & $75(8.1)$ & 0.690 \\
\hline Further Training Conditions & $1(0.3)$ & $4(0.4)$ & 0.746 & $35(11.0)$ & $74(8.0)$ & 0.100 \\
\hline Meaning & $2(0.6)$ & $1(0.1)$ & 0.106 & $1(0.3)$ & $1(0.1)$ & 0.427 \\
\hline Income & $1(0.3)$ & $2(0.2)$ & 0.767 & $69(21.6)$ & $215(23.1)$ & 0.584 \\
\hline Not codeable & $10(3.1)$ & $26(2.8)$ & 0.790 & $9(2.8)$ & $27(2.9)$ & 0.940 \\
\hline Total & $324(100)$ & $929(100)$ & & $319(100)$ & $930(100)$ & \\
\hline
\end{tabular}

Values in parentheses are percentages. $\ddagger x^{2}$ test.

Table 4: Frequency distribution of statements in favour of $(n=1,253)$ and against $(n=1,249)$ a career in Primary Care given by 302 final-year students and 112 first-year to fourth-year medical students. 


\begin{tabular}{|c|c|c|c|c|c|c|}
\hline Category & Statem & vour of a c & ry Care & Statemen & $t$ a career & Care \\
\hline Is your mother/father a PCP? & No & Yes & $P \ddagger$ & No & Yes & $P \ddagger$ \\
\hline Experience in Daily Practice & $532(47.0)$ & $68(58.6)$ & 0.017 & $280(24.9)$ & $25(21.0)$ & 0.344 \\
\hline Professional Interactions & $397(35.1)$ & $37(31.9)$ & 0.490 & $40(3.6)$ & $3(2.5)$ & 0.555 \\
\hline Working Conditions & $122(10.8)$ & $5(4.3)$ & 0.028 & $275(24.5)$ & $31(26.1)$ & 0.707 \\
\hline Private Life & $28(2.5)$ & $2(1.7)$ & 0.615 & $46(4.1)$ & $8(6.7)$ & 0.182 \\
\hline Prestige & $9(0.8)$ & $0(0)$ & 0.335 & $91(8.1)$ & $12(10.1)$ & 0.456 \\
\hline Further Training Conditions & $4(0.4)$ & $1(0.9)$ & 0.409 & $101(9.0)$ & $8(6.7)$ & 0.405 \\
\hline Meaning & $2(0.2)$ & $1(0.9)$ & 0.151 & $1(0.1)$ & $1(0.8)$ & 0.052 \\
\hline Income & $2(0.2)$ & $1(0.9)$ & 0.151 & $255(22.7)$ & $29(24.4)$ & 0.681 \\
\hline Not codeable & $35(3.1)$ & $1(0.9)$ & 0.171 & $34(3.0)$ & $2(1.7)$ & 0.405 \\
\hline Total & $1131(100)$ & $116(100)$ & & $1123(100)$ & $119(100)$ & \\
\hline
\end{tabular}

Values in parentheses are percentages. PCP: Primary Care Physician. $\ddagger X^{2}$ test.

Table 5: Frequency distribution of statements in favour of $(n=1,247)$ and against $(n=1,242)$ a career in Primary Care given by 374 students without a PCP as parents and 37 students with a PCP as parents (3 missing values).

\begin{tabular}{|c|c|c|c|c|c|c|}
\hline \multirow{2}{*}{\begin{tabular}{l}
\multicolumn{1}{c}{ Category } \\
Would you choose Primary Care \\
as a career?
\end{tabular}} & \multicolumn{3}{|c|}{ Statements in favour of a career in Primary Care } & \multicolumn{3}{|c|}{ Statements against a career in Primary Care } \\
\hline & Yes & No & $\mathrm{P} \ddagger$ & Yes & No & $P \ddagger$ \\
\hline Experience in Daily Practice & $88(45.1)$ & $515(48.7)$ & 0.362 & $29(15.9)$ & $278(26.1)$ & 0.003 \\
\hline Professional Interactions & $78(40.0)$ & $359(33.9)$ & 0.102 & $5(2.7)$ & $38(3.6)$ & 0.578 \\
\hline Working Conditions & $13(6.7)$ & $114(10.8)$ & 0.081 & $53(29.1)$ & $257(24.1)$ & 0.146 \\
\hline Private Life & $5(2.6)$ & $25(2.4)$ & 0.866 & $10(5.5)$ & $45(4.2)$ & 0.438 \\
\hline Prestige & $1(0.5)$ & $8(0.8)$ & 0.712 & $15(8.2)$ & $88(8.2)$ & 0.998 \\
\hline Further Training Conditions & $3(1.5)$ & $2(0.2)$ & 0.006 & $12(6.6)$ & $97(9.1)$ & 0.270 \\
\hline Meaning & $0(0)$ & $3(0.3)$ & 0.457 & $0(0)$ & $2(0.2)$ & 0.559 \\
\hline Income & $0(0)$ & $3(0.3)$ & 0.457 & $53(29.1)$ & $231(21.6)$ & 0.026 \\
\hline Not codeable & $7(3.6)$ & $29(2.7)$ & 0.514 & $5(2.7)$ & $31(2.9)$ & 0.906 \\
\hline Total & $195(100)$ & $1058(100)$ & & $182(100)$ & $1067(100)$ & \\
\hline
\end{tabular}

Values in parentheses are percentages. $\mp X^{2}$ test.

Table 6: Frequency distribution of statements in favour of $(n=1,253)$ and against $(n=1,249)$ a career in Primary Care given by 59 students who would choose Primary Care and 355 (including 118 undecided) who would not choose Primary Care as a career at the day of survey.

almost the same for all participants, regardless of study year and career aspiration, with significant more positive statements given by PCP progenies in the category, "Experience in Daily Practice". Sixthyear students and younger medical students obviously like to care for people and to combine intellectual knowledge and practical skills for the patients' treatment. The intention "Helping people" is one of four generic motivation factors described by McManus et al. which was already found in the very beginning of one's career in medicine, among medical school applicants [24], and which remains stable throughout the residency [4]. Therefore, it seems that these positive statements are not necessarily typical for Primary Care, but statements which apply to any speciality in medicine. Male participants, Primary Care progenies, and sixth-year medical students gave significantly fewer positive statements in the category, "Working Conditions". Although some authors have shown that clinical exposure was critical for demonstrating the positive aspects of family medicine [6], and that exposure to clinical settings encourages students to choose a career in the corresponding category [25], in our study previous exposure to a PCP within one's own family or during tutorials in the study with direct contact to the current working environment did not lead participants assess "Working Conditions" any more positively compared to others. In fact, unsatisfactory working conditions and low work control play major roles in not selecting a certain career by students [25], and are the major contributor to the development of burnout in physicians $[8,26,27]$. In contrast, and in accordance with others, gender played no clear role as predictor of speciality choice toward Primary Care in our study $[25,28]$. Unsurprisingly, the least-mentioned positive statements were in the categories "Income", "Further Training Conditions", and "Prestige". There is a widening gap in income between PCP and specialists; specialists were seen not only to have a greater control over their lives and a wider variety of professional experiences, but also higher incomes [29], and this could be a modifier in students' lack of interest to become a PCP [30]. Besides income, it is the financial uncertainty of the PCP in the future that makes Primary Care unattractive and avoided by students $[16,17]$.

The statements against a career in Primary Care might highlight the aforementioned statements: besides the unfavourable working environment, where sixth-year medical students with contacts with Primary Care during one-to-one tutorials give more negative statements than do younger students, and besides the curtailed freedom of action, there are, above all, negative statements in the category, "Income", with significantly fewer negative statements of participants rejecting PCP as a career than of others. The latter are concerned about low income and assess the remuneration as a deterrent for PC as a career; but it seems that students who judge Primary Care as important have low income expectations and are settled for a breadth of knowledge with a narrow room of action at the same time [31], apparent with the most striking difference between participants aspiring to become a PCP and those who do not, with significantly fewer negative statements in the category, "Experience in Daily Practice", for PCP aspirants. A gender stereotype was not detectable in our study.

The majority of students choosing Primary Care as a career decided already at entry to medical school or at the beginning of residency and 
the career intention at entry to medical school even predict speciality career choice [32]. Contrary to others who have shown that there is a significant change of career choice during medical school or residency due either to a lifestyle that is not controllable, to positive clinical exposure, to economics constraints, or to discouragement by a physician [31,33], we found a significantly higher interest in a career in Primary Care in sixth-year medical students than in younger students. Even if each of these interested participants would consistently track his or her career choice throughout the residency, there would still be too few physicians to fill the need for PCPs in the future. Affirmative action should be implemented soon.

Our results should be viewed with some caution. First, we used a cross-sectional design that obviates evaluation of the evolution of career-choice decision-making throughout medical school and the cause-and-effect relationship of attitude to Primary Care with factors, such as candidates' personalities or other predictive factors for the likelihood of choosing Primary Care. We do not yet know how many of the students will become a PCP later on. Second, there may be some selection bias with our approach of including students from three major German-speaking Swiss medical universities. Thus, our results may not be generalisable to the French-speaking part of Switzerland. Finally, non-response bias cannot be excluded. Unfortunately, an interview with a sample of non respondents to assess their opinions for and against Primary Care was not possible due to the anonymity, with which this survey was conducted. However, the study was conducted on a fairly large number of medical students and the response rate was favourable compared to other surveys [34].

In summary, the qualitative approach has not made apparent any one distinctive category of statements in favour of a career in Primary Care. Nonetheless, the given statements assigned to the different categories have highlighted the difficult and uncertain situation and development of Primary Care regarding health policy and income. With the increasing burden of chronic illness and complexity of medical care, coordinating care across settings and providers will gain particular importance [35]. Therefore, there is an urgent need to increase the attractiveness of Primary Care, with a widening of the PCP professional experiences and a secure remuneration appropriate to specialists' level. Implementation and extension of one-on-one studentPCP tutorials as one of the most important factors that influence career choice regarding Primary Care and more structured and harmonised curricula in residency is essential. Finally, reduction in the extremely high workload and transformation into a more controllable medical life will be crucial to attract more young physicians to the profession of Primary Care.

\section{Acknowledgments}

We gratefully acknowledge the students who took part in this study for their time and invaluable comments. We thank Ursina Caminada for data administration Ulrich Stefenelli, (Services-in-statistics, Wurzburg, Germany) for scientific support; and Phillip Hendrickson, Ph.D., Basel, Switzerland, for critical reading.

\section{References}

1. http://www.obsan.admin.ch/bfs/obsan/de/index/05/publikationsdatenbank. Document.110590.pdf

2. http://www.obsan.admin.ch/bfs/obsan/de/index/01/01.Document.110768.pdf

3. Whitcomb ME, Cohen JJ (2004) The future of primary care medicine. N Engl J Med 351: 710-712.

4. Buddeberg-Fischer B, Dietz C, Klaghofer R, Buddeberg C (2006) Swiss residents' arguments for and against a career in medicine. BMC Health Serv Res 6: 98.
5. Walker HK (2006) Primary care is dying in the United States: mutatis mutandis. Med Educ 40: 9-11.

6. Scott I, Wright B, Brenneis F, Brett-Maclean P, McCaffrey L, et al. (2007) Why would I choose a career in family medicine?: Reflections of medical students at 3 universities. Can Fam Physician 53: 1956-1957.

7. De Maeseneer J (2005) Why does a Medical Faculty need family medicine for international accreditation. PrimaryCare 5: 272-274.

8. Goehring C, Bouvier Gallacchi M, Künzi B, Bovier P (2005) Psychosocial and professional characteristics of burnout in Swiss primary care practitioners: a cross-sectional survey. Swiss Med Wkly 135: 101-8.

9. Soler JK, Yaman H, Esteva M, Dobbs F, Asenova RS, et al. (2008) Burnout in European family doctors: the EGPRN study. Fam Pract 25: 245-265.

10. Newton DA, Grayson MS, Thompson LF (2005) The variable influence of lifestyle and income on medical students' career specialty choices: data from two U.S. medical schools, 1998-2004. Acad Med 80: 809-14.

11. Buddeberg-Fischer B, Stamm M, Buddeberg C, Klaghofer R (2008) [Young physicians' view on factors that increase the attractiveness of general practice]. Gesundheitswesen 70: 123-128.

12. Scott I, Gowans MC, Wright B, Diet MN (2007) Why medical students switch careers: changing course during the preclinical years of medical school. Can Fam Physician 53: 94-95.

13. Compton MT, Frank E, Elon L, Carrera J (2008) Changes in U.S. medical students' specialty interests over the course of medical school. J Gen Intern Med 23: 1095-1100.

14. Jeffe DB, Andriole DA, Hageman HL, Whelan AJ (2007)The changing paradigm of contemporary U.S. allopathic medical school graduates' career paths: analysis of the 1997-2004 national AAMC Graduation Questionnaire database. Acad Med 82: 888-894.

15. Bodenheimer T, Grumbach K, Berenson RA (2009) A lifeline for primary care N Engl J Med 360: 2693-2696.

16. Wass CT, Rose SH, Faust RJ, Offord KP, Harris AM et al. (1999) Recruitment of house staff into anesthesiology: factors responsible for house staff selecting anesthesiology as a career and individual training program. J Clin Anesth 11: 150-163.

17. Miller RD, Lanier WL (2001) The shortage of anesthesiologists: an unwelcome lesson for other medical specialties. Mayo Clin Proc 76: 969-970.

18. Sandy LG, Schroeder SA (2003) Primary care in a new era: disillusion and dissolution?. Ann Intern Med 138: 262-267.

19. Thistlethwaite JE, Leeder SR, Kidd MR, Shaw T (2008) Addressing general practice workforce shortages: policy options. Med J Aust 189:118-121.

20. Glazner C (2008) Dinosaurs, hospital ecosystems, and the future of family medicine. Ann Fam Med 6: 368-369.

21. Buddeberg-Fischer B, Klaghofer R, Stamm M, Marty F, Dreiding P et al. (2006) Primary care in Switzerland--no longer attractive for young physicians?. Swiss Med Wkly 136: 416-424.

22. Buddeberg-Fischer B, Stamm M, Buddeberg C, Klaghofer R (2008) The new generation of family physicians--career motivation, life goals and work-life balance. Swiss Med Wkly 138: 305-312.

23. Mayring P (2003) Qualitative Inhaltsanalyse. Grundlagen und Techniken. Beltz, Weinheim.

24. McManus IC, Livingston G, Katona C (2006) The attractions of medicine: the generic motivations of medical school applicants in relation to demography, personality and achievement. BMC Med Educ 6: 11.

25. Maiorova T, Stevens F, Scherpbier A, van der Zee J et al. (2008) The impact of clerkships on students' specialty preferences: what do undergraduates learn for their profession?. Med Educ 42: 554-562.

26. Linzer M, Visser MR, Oort FJ, Smets EM, McMurray JE, et al. (2001) Predicting and preventing physician burnout: results from the United States and the Netherlands. Am J Med 111: 170-175.

27. Taylor C, Graham J, Potts HW, Richards MA, Ramirez AJ, et al. (2005) Changes in mental health of UK hospital consultants since the mid-1990s. Lancet 366: 742-744.

28. Maiorova T, Stevens F, van der Zee J, Boode B, Scherpbier A, et al. (2008) 
Citation: Burghardt LR, Dreisbach M, Shahla H, Businger AP (2012) Swiss Student's Arguments in Favour and against a Career in Primary Care. Primary Health Care 2:114. doi:10.4172/2167-1079.1000114

Shortage in general practice despite the feminisation of the medical workforce: a seeming paradox? A cohort study. BMC Health Serv Res 8: 262.

29. Steinbrook R (2009) Easing the shortage in adult primary care--is it all about money? N Engl J Med 360: 2696-2699.

30. Morra DJ, Regehr G, Ginsburg S (2009) Medical students, money, and caree selection: students' perception of financial factors and remuneration in family medicine. Fam Med 41: 105-110.

31. Bowman MA, Haynes RA, Rivo ML, Killian CD, Davis PH, et al. (1996) Characteristics of medical students by level of interest in family practice. Fam Med 28: 713-719.
32. Senf JH, Campos-Outcalt D, Kutob R (2003) Factors related to the choice of family medicine: a reassessment and literature review. J Am Board Fam Pract 16: $502-512$

33. Schafer S, Shore W, French L, Tovar J, Hughes S, et al. (2000) Rejecting family practice: why medical students switch to other specialties. Fam Med 32: $320-325$.

34. Sreeramareddy CT, Shankar PR, Binu VS, Mukhopadhyay C, Ray B, et al. (2007) Psychological morbidity, sources of stress and coping strategies among undergraduate medical students of Nepal. BMC Med Educ 7:26.

35. Bodenheimer $\mathrm{T}$ (2008) Coordinating care--a perilous journey through the health care system. N Engl J Med 358: 1064-1071. 